\title{
KEBIJAKAN PEMBERIAN TAMBAHAN PERBAIKAN PENGHASILAN PEMERINTAH KABUPATEN KEDIRI
}

\author{
The Additional Refinement Income Policy In Kediri Regency
}

\author{
Anang Siswahyudi ${ }^{1}$ \\ ${ }^{1}$ Magister Ilmu Administrasi Universitas Kadiri
}

\begin{abstract}
Abstrak
Penelitian ini Kebijakan Pemberian Tambahan Penghasilan Penghasilan di Pemerintah Kabupaten Kediri. Hasilnya menunjukkan bahwa: 1. Proses penyusunan kebijakan berjalan secara terencana dan sistematis sesuai tahapan perumusan kebijakan. Dalam masalah identifikasi formulasi kebijakan telah didasarkan pada isu-isu strategis seperti a). kondisi realitas kinerja karyawan cenderung lebih rendah, b). tingkat kesejahteraan dan tingkat perbedaan pendapatan bagi karyawan. Dalam mengambil model atau alternatif pemilihan kebijakan merupakan proses antar ras antar elit aktor birokrasi di pemerintah kabupaten Kediri yang mempengaruhi bentuk penentuan kebijakan tambahan penyempurnaan pendapatan 2). Bentuk kebijakan tambahan penyempurnaan pendapatan pemerintah kabupaten Kediri diperoleh melalui tiga variabel: posisi, kehadiran dan kinerja karyawan; 3). Dalam pelaksanaan kebijakan peningkatan pendapatan tambahan telah didukung oleh sistem dan kebijakan yang ada dalam sistem online jari terhadap kehadiran karyawan dan variabel kinerja melalui instrumen pencapaian kinerja yang dibuat pada akhir tahun. Dalam pelaksanaan variabel lain berdasarkan posisi, dalam pelaksanaan ketiga variabel tersebut tampak kurang efektif dalam hal variabel kinerja karena tidak mencerminkan kinerja karyawan setiap hari, sedangkan dalam akuisisi kebijakan peningkatan tambahan pendapatan masih dirasakan disparitas antara karyawan staf dengan karyawan struktural akibatnya belum dapat meningkatkan kinerja secara signifikan kepada karyawan tingkat yang lebih rendah.
\end{abstract}

Kata Kunci: Perumusan Kebijakan; Implementasi; Kinerja Pegawai

\begin{abstract}
This research aims to describe the implementation of additional refinement income policy in Kediri Regency. The result shows that: 1. The process of compiling policy runs in a planned and system according to the stage of policy formulation. In identification issues of administration, the wording has been based on strategic topics such as a). The condition of the reality of the performance of employees tends to be lower, $b$ ). The level of welfare and income disparities rate for employees. In taking the model or the alternative selection of policy is an interracial process between bureaucracy elite actors in the district government of Kediri which influences the form of additional refinement income policy determination 2). The type of other refinement income policy of Kediri district government is acquired through three variables: position, presence, and employee performance; 3). In the implementation of additional refinement, income policy has been supported by the system, and the existing plan in the operation of finger online towards employee attendance and performance variables through the instrument of performance achievement is made at the end of the year. In the implementation of the other variables based on positions. In the application of the three variables seem less effective in terms of performance variables because it does not reflect the performance of employees every day, while in the acquisition of additional refinement income policy is still perceived disparities between staff employees with the structural employees consequently have not been able to improve performance significantly to the lower level employees.
\end{abstract}

Keywords: Policy Formulation; Implementation; Employee Performance

A. PENDAHULUAN

Memasuki abad ke-21 dan milenium III, salah satu tantangan besar yang dihadapi oleh aparatur pemerintah daerah adalah bagaimana menampilkan profesionalisme, etos kerja tinggi, keunggulan kompetitip dan kemampuan memegang teguh etika birokrasi dalam menjalankan tugas dan fungsinya sesuai dengan aspirasi masyarakat yang bebas dari nuansa KKN. Tantangan tersebut merupakan suatu hal yang beralasan, mengingat secara empirik masyarakat menginginkan peranan aparatur pemerintah 
dapat menjalankan tugas-tugas pelayanan secara optimal. Tumpuan dari harapan-harapan itu sendiri kini lebih tertuju pada institusi pemerintah daerah agar dapat mewujudkan kepemerintahan yang baik (good governance).

Remunerasi pemerintahan adalah merupakan bagian yang tidak terpisahkan dari Kebijakan Reformasi Birokrasi. Dilatarbelakangi oleh kesadaran sekaligus komitmen pemerintah untuk mewujudkan clean and good governance. Namun pada tataran pelaksanaannya, perubahan dan pembaharuan yang dilaksanakan dalam rangka mewujudkan tata pemerintahan yang bersih dan berwibawa tersebut tidak mungkin akan dapat dilaksanakan dengan baik (efektif) tanpa kesejahteraan yang layak dari pegawai.

Tunjangan Kinerja (remunerasi) adalah salah satu bentuk sistem pembayaran tunjangan yang mengkaitkan imbalan (reward) dengan prestasi kerja (performance). Implikasi dari konsep tersebut adalah bahwa seseorang yang berkinerja baik maka akan memperoleh imbalan yang lebih tinggi dan begitu pula sebaliknya. Artinya, semakin tinggi kinerja yang dapat dicapai seorang pegawai, maka akan makin tinggi pula imbalannya. Dengan demikian jika sistem ini dapat diterapkan secara efektif maka akan berdampak positif bagi sebuah organisasi karena akan dapat meningkatkan kinerja dan kepuasan kerja pegawai. Secara umum, dasar hukum kebijakan pemberian tunjangan kinerja di atas, bersumber dari Peraturan Pemerintah Nomor 58 Tahun 2005 tentang Pengelolaan Keuangan Daerah dan Peraturan Menteri Dalam Negeri Nomor 13 Tahun 2006 tentang Pedoman Pengelolaan Keuangan Daerah. Dalam pasal 63 ayat (2) Peraturan Pemerintah Nomor 58 Tahun 2005 dinyatakan bahwa "Pemerintah daerah dapat memberikan tambahan penghasilan kepada pegawai negeri sipil daerah berdasarkan pertimbangan yang obyektif dengan memperhatikan kemampuan keuangan daerah dan memperoleh persetujuan DPRD sesuai dengan ketentuan peraturan perundangundangan. Tambahan penghasilan diberikan dalam rangka peningkatan kesejahteraan pegawai berdasarkan prestasi kerja, tempat bertugas, kondisi kerja dan kelangkaan profesi.

Petunjuk teknis terhadap kebijakan pemberian tambahan penghasilan oleh pemerintah daerah ditegaskan melalui Peraturan Menteri Dalam Negeri Nomor 13 Tahun 2006 tentang Pedoman Pengelolaan Keuangan Daerah, yang terakhir diubah dengan Permendagri Nomor 21 Tahun 2011, pasal 39 ayat (1) yang menyatakan bahwa "Pemerintah Daerah dapat memberikan tambahan penghasilan kepada pegawai negeri sipil berdasarkan pertimbangan yang obyektif dengan memperhatikan kemampuan keuangan daerah dan memperoleh persetujuan DPRD sesuai dengan ketentuan peraturan perundang-undangan". Analisis terhadap kedua peraturan tersebut mengandung syarat diterapkannya kebijakan tambahan penghasilan oleh pemerintah daerah, yaitu untuk peningkatan kesejahteraan pegawai, ada dasar pertimbangan yang obyektif, besarannya sesuai dengan kemampuan keuangan daerah.

Berdasarkan pemikiran tersebut di atas, maka penulis tertarik untuk melakukan penelitian kebijakan Tambahan Perbaikan Penghasilan (TPP) bagi PNS di Pemerintah Kabuapten Kediri guna memperoleh gambaran proses perumusan dan penerapan tunjangan perbaikan penghasilan yang apakah searah dengan pemenuhan kebijakan pemerintah pusat. Sehingga, dalam proses penyesuaiannya (alignment) dapat dilakukan secara sistematis dan simultan sesuai dengan tahapan yang dimaksud pemerintah pusat.

Dari latar belakang permasalahan yang dikemukakan diatas maka penulis merumuskan masalah yang akan dikaji, yaitu :

1. Bagaimanakah Proses Perumusan kebijakan Pemberian tambahan penghasilan bagi pegawai negeri sipil pemerintah kabupaten kediri?

2. Bagaimanakah bentuk kebijakan Pemberian tambahan penghasilan bagi pegawai negeri sipil pemerintah kabupaten kediri?

3. Bagaimanakah Pelaksanaan kebijakan Pemberian tambahan penghasilan bagi pegawai negeri sipil pemerintah kabupaten kediri?

\section{B. KERANGKA TEORI Kebijakan Publik}

Kebijakan publik merupakan "whatever governments choose to do or not to do" segala sesuatu yang dipilih oleh pemerintah, yang dikerjakan ataupun yang tidak dikerjakan (Dyee,1978). Selanjutnya Dye menyatakan apabila pemerintah memilih untuk melakukan kebijakan publik, maka harus mengutamakan goal (objektifnya) dan merupakan tindakan keseluruhan bukan hanya perwujudan keinginan pemerintah atau pejabat pemerintah saja.

Dalam memecahkan masalah yang dihadapi kebijakan publik, terdapat beberapa tahap (Dunn,1994) yaitu : penetapan agenda kebijakan (agenda setting), formulasi kebijakan (policy formulation), adopsi kebijakan (policy adoption), implementasi kebijakan (policy implementation) dan penilaian kebijakan (policy assesment).

Menurut Anderson \{Islami, 1994) perumusan kebijakan publik meyangkut upaya menjawab pertanyaan bagaimana berbagai 
alternative disepakati untuk masalah-masalah yang dikembangkan dan siapa yang berpartisipasi. Sedangkan pembuatan kebijakan lebih merujuk pada aspek-aspek lain seperti bagaimana masalah-masalah publik menjadi perhatian para pembentuk kebijakan, seperti bagaimana masalah-masalah publik menjadi perhatian para pembentuk kebijakan, bagaimana proposal kebijakan dirumuskan untuk masalahmasalah khusus, dan bagaimana kebijakan merupakan keseluruhan tahap dalam kebijakan publik yeng berupa rangkaian keputusan.

Masalah yang masuk dalam agenda kebijakan selanjutnya akan dibahasa oleh actor perumus kebijakan. Masalah tersebut dibahas sesuai tingkat urgensinya dalam pemecahannya. Tahap dalam formuasi kebijakan menurut Pasolong (2010:42-52) adalah dimana kebijakan dianalisis kemudian dicari fomulasi terbaiknya melalui Identifikasi masalah, Badjur (Pasolong, 2007, p. 42) mengatakan bahwa pada dasarnya kebijakan publik terjadi karena adanya masalah yang perlu ditangani secara serius. Tanpa adanya masalah, barang kali tidak akan pernah dibuat kebijakan publik. Informasi mengenai masalah kebijakan dapat diperoleh melalui sumber tertulis sepertildentifikasi masalah, Badjur (Pasolong, 2007, p. 42) mengatakan bahwa pada dasarnya kebijakan publik terjadi karena adanya masalah yang perlu ditangani secara serius. Pertanyaan penting yang harus dijawab pada tahap identifikasi masalah adalah: seperti 1. Apa Apa isu itu benar-benar masalah?, 2. Siapa sasarannya? 3. Apa alasan atau apa buktinya?, 4. Apa masalah itu sudah sangat mendesak/urgen? 5. Apakah akibat negative yang terjadi akan signifikan apabila tidak segera diintervensi?

Setelah proses penetapan kebijakan selesai, maka kebijakan publik diimplementasian. Gordon (1986), mengatakan bahwa implementasi berkenaan dengan berbagai kegiatan yang diarahkan pada realisasi program. Dalam hal ini, administrator mengatur cara untuk mengorganisir, menginterpretasikan dan menerapkan kebijakan yang telah diseleksi. Mengorganisir berarti mengatur sumber daya, unit-unit dan metode-metode untuk melaksanakan program. Melakukan interpretasi berkenaan dengan mendefinisikan istilah-istilah program ke dalam rencana-rencana dan petunjukpetunjuk yang dapat diterima dan feasible. Menerapkan berarti menggunakan instrumentinstrumen atau memberikan pelayanan rutin, melakukan pembayaran-pembayaran.

Secara luas, implementasi dapat didefinisikan sebagai proses administrasi dari hukum (statute) yang didalamnya tercakup keterlibatan berbagai actor, organisasi, prosedur, dan teknik yang dilakukan agar kebijakan yang ditetapkan mempunyai akibat, yaitu tercapainya suatu tujuan. Dari dua pengertian implementasi diatas dapat ditafsirkan bahwa kebijakankebijakan diimplementasikan belum tentu dapat mencapai tujuannya. Selain pengertian diatas, implementasi kebijakan dipahami sebagai suatu proses, output, dan outcome. Implementasi dapat dikonseptualisasikan sebagai proses karena didalamnya terjadi beberapa rangkaian aktivitas yang berkelanjutan.

\section{Konsep tentang Tunjangan/Insentif}

Pengertian tunjangan menurut Simamora (2004) adalah pembayaran-pembayaran dan jasajasa yang melindungi dan melengkapi gaji pokok, dan organisasi dapat membayar semua atau sebagian dari tunjangan terebut. Dalam kamus besar Bahasa Indonesia, pengertian tunjangan yang disesuaikan dengan topik bahasan ini adalah tambahan pendapatan di luar gaji sebagai bantuan, sokongan. Pada kenyataannya sektor publik mempunyai beberap karakteristik spesifik yang membuat desain skema insentif sangat kompleks (Pollit, 2006; Anthony dan Young, 2003 dalam verbeeten 2008; Burgess dan Ratto, 2003; Tirole, 1994). Pertama, organisasi sektor publik secara umum mempunyai banyak stakeholder (principal) dengan tujuan yang banyak juga, Kedua, beberapa dimensi kinerja sulit untuk diukur.

\section{Kinerja}

Menurut Wirawan (2009), kinerja adalah keluaran yang dihasilkan oleh fungsi-fungsi atau indikator-indikator suatu pekerjaan atau suatu profesi dalam waktu tertentu. Kinerja merujuk pada pencapaian karyawan atas tugas yang diberikan (Cascio, 1992 dalam Marifah, 2004). Kinerja pada hakekatnya adalah hasil kerja yang dapat dicapai oleh seseorang atau sekelompok orang dalam organisasi, sesuai dengan wewenang dan tanggung jawab masing-masing, dalam rangka mencapai tujuan organisasi (Prawisosentono, 1992 dalam Marifah, 2004).

Soedjono dalam Mariam (2009) menyebutkan 6 (enam) kriteria yang dapat digunakan untuk mengukur kinerja pegawai secara individu yakni: 1. Kualitas, hasil pekerjaan yang dilakukan mendekati sempurna atau memenuhi tujuan yang diharapkan dari pekerjaan tersebut.

2. Kuantitas, jumlah yang dihasilkan atau jumlah aktivitas yang dapat diselesaikan.

3. Ketepatan waktu, yaitu dapat menyelesaikan pada waktu yang telah ditetapkan serta memaksimalkan waktu yang tersedia untuk aktivitas yang lain. Efektivitas pemanfaatan secara maksimal sumber daya yang ada pada 
organisasi untuk meningkatkan keuntungan dan mengurangi kerugian.

4. Kemandirian, yaitu dapat melaksanakan kerja tanpa bantuan guna menghindari hasil yang merugikan.

5. Komitmen kerja, yaitu komitmen kerja antara pegawai dengan organisasinya. Tanggung jawab pegawai terhadap organisasinya

\section{METODE PENELITIAN}

Mengacu pada tujuan penulisan ini yakni untuk menggambarkan proses perumusan kebijakan pemberiaan tambahan Perbaikan Pengasilan di pemerintah Kabupaten Kediri, maka pendekatan yang digunakan dalam penelitian ini adalah penelitian Kualitatif dengan rancangan penelitian studi kasus. Di mana penelitian studi kasus Menurut creswell (2009) adalah merupakan salah satu jenis penelitian kualitatif, dimana peneliti melakukan explorasi secara mendalam terhadap program, kejadian, proses, aktivitas, terhadap satu atau lebih orang. Studi kasus terikat oleh waktu dan aktivitas dan peneliti melakukan pengumpulan data secara mendetail dengan berbagai prosedur pengumpulan data dalam waktu berkesinambungan.

\section{PEMBAHASAN \\ Pelaksanaan Kebijakan Pemberian Tambahan Perbaikan Penghasilan}

Dalam pelaksanaan Kebijakan Pemberian Tambahan Perbaikan Penghasilan bagi Pegawai Negeri Sipil ada beberapa kondisi yang mendukung pelaksanaan penerapan TPP antara lain Pemerintah Kabupaten Kediri sudah menerapkan instrumen penilaian prestasi kerja bentuk isian dokumen Sasaran Kerja Pegawai (SKP) dan penilaian perilaku oleh atasan yang merupakan salah satu bagian dari 3 variabel yang adan di kebijakan tambahan perbaikan penghasilan yaitu variabel kinerja. Sistem penilaian prestasi kerja ini baru mulai diterapkan sejak tahun 2014 dan untuk penilaian prestasi kerja ASN ini dilaksanakan sekali dalam 1 (satu) tahun.

Pemerintah Kabupaten Kediri sudah menggunakan sistem presensi online dengan finger print. Aplikasi presensi ini ada di setiap SKPD dan langsung tersambung secara online dengan Badan Kepegaian Daerah (BKD) sebagai dasar evaluasi kehadiran dan kebijakan lainnya. Output sistem ini berupa laporan kehadiran setiap individu.
Pemerintah Kabupaten sudah memiliki sistem kepegawaian yang secara tertib dan periodik mendata dan mengelola data-data kepegawaian mulai dari eselon IIa sampai dengan staf. Data ini sangat penting sebagai dasar untuk menentukan salah satu variabel dalam kebijakan Tambahan Perbaikan penghasilan.

Dalam pelaksanaan masih terlihat Pegawai yang hadir tepat waktu dan pulang tepat waktu serta selama jam kerja selalu berada di kantor bukan berarti akan berkontribusi pada kantor. Adakalanya pegawai tersebut hanya menganggur di kantor atau hanya sekedar menghabiskan waktu baca koran di kantor sampai jam kantor selesai. Untuk kondisi inipun kantor tidak mendapatkan manfaat apapun dari keberadaan pegawai tersebut.

Dari uaraian pembahasan diatas bahwa pelaksanaan kebijakan pemberian tambahan penghasilan dilakukan melalui tiga variabel yaitu salah satunya variabel kinerja yang diperoleh melalui Penilaian ASN berdasarkan prestasi kerja ini sebenarnya cukup bagus, tetapi masih mengalami permasalahan didalam penerapannya terutama berkaitan dengan penilaian dan pemberian tunjangan pegawai karena berlaku pada pemberian tunjangan pada tahun berikutnya sehinga kurang memberikan dampak terhadap peningkatan kinerja pegawai.

\section{E. KESIMPULAN DAN REKOMENDASI}

Dari hasil penelitian dengan mengacu pada tujuan peneltian yang telah disusun pada bab pendahuluan dengan kesimpulan sebagai berikut:

1) Proses penyusunan kebijakan peraturan bupati kediri nomor 16 tahun 2015 tentang pemberian tambahan perbaikan penghasilan pegawai berjalan secara terencana dan sitematis sesuai sesuai tahapan dalam perumusan kebijakan. Dalam indentifkasi permasalahan perumusan kebijakan sudah didasarkan pada isu isu strategis seperti a). kondisi realitas kinerja pegawai cenderung masih rendah, b). tingkat kesejahteraan dan adanya kesenjangan tingkat perolehan penghasilan bagi pegawai, c) total belanja pegawai pemerintah daerah kabupaten Kediri. Dalam menyusun bentuk atau isi kebijakan merupakan proses interaksi antara aktor-aktor elit birokrasi, pengaruh besarnya kewenangan bisa terlihat ketika Inspektorat terlibat dalam finalisasi isi kebijakan yang menimbulkan tingkat perolehan tambahan penghasilan cenderung kurang kosisten karena 
memasukan fungsional auditor (staf) perolehannya setara dengan jabatan eselon IV/a.

2) Bahwa bentuk kebijakan tambahan perbaikan penghasilan melalui 3 variabel yaitu jabatan, kehadiran dan kinerja.

3) Dalam pelaksanaan kebijakan tambahan perbaikan penghasilan dalam hal variabel kehadiran yang sudah didukung oleh sistem finger print online dan dalam variabel kinerja telah didukung oleh sistem penilian perestasi kerja pegawai yang dibuat satu kali dalam satu tahun sehinga dalam pelaksanaanya pemberian tambahan perbaikan penghasilan dapat berjalan secara baik.

4) Dalam pelaksanaan pemberian tambahan perbaikan penghasilan pengaruh yang ditimbulkan bagi staf fungsional masih diraskan terlalu timpang justru tidak menimbulkan semangat untuk bekerja bahkan sebaliknya menimbulkan suasana kecemburuan suasana tidak menyenangkan di lingkungan kerja. Bila di lihat dari segi kinerja maka dikaitkan dengan target pelayanan kantor, maka kita tidak akan tahu apakah pegawai tersebut telah berkinerja dengan baik, Sehinga jadi masalah dalam sistem ini adalah walaupun seorang pegawai tidak berkinerja pada saat ini tetap bisa dibayar TPP nya karena dasar perhitungan TPP adalah kinerja tahun lalu sehinga pelaksanaannya tidak memberikan dampak yang kurang signifikan terhadap peningkatan kinerja pegawai.

\section{E. REFERENSI}

Abdul Solichin Wahab, 2012. Analisis Kebijakan Dari Formulasi ke Penyusunan ModelModel Implementasi Kebijakan Publik. Jakarta- Bumi Aksara

Adnan Mahdi, 2014. Paduan Penelitian Praktis Untuk Menyusun Skripsi, Tesis dan Desertasi. Bandung: Alfabeta

Cochran, L. Charles and Malone. F. Eloise. 2010. Publik Police - Perpectives and Choices. London

Dye, R. Thomas, 2002.Understanding Publik Police - Tenth Edition. American

Dye, R. Thomas, 1976.Policy analysis - What Goverment do, why they do it, andwhat difference it makes. American: Alabama

Dunn, N. William, 2000. Pengantar Analisis Kebijakan Publik. Yogyakarta: Gajah Mada University Press

Gordon, G.J. 1986. Public Administration in America, New York: St.Martin's Press.

Harbani Pasolong. 2008. Kepemimpinan birokrasi. Bandung. Alfabeta
Hariandja, Marihot T.E, 2002. Manajemen Sumber Daya Manusia. Grasindo. Jakarta.

Islamy, Irfan, M. 1994. Prinsip-prinsip Perumusan Kebijaksanaan Negara. Jakarta: Bumi Aksara.

Islami, M. Irfan.,1998.Agenda Kebijakan Reformasi Administrasi Negara, Malang.Fakultas ilmu admnistrasiUniversitas Brawijaya

Jurnal Kebijakan dan Manajemen PNS Vol. 8, No.2, November 2014: Pusat Pengkajian dan Penelitian Kepegawian BKN

Journal Administrasi Negara, 2015: , 3 (1) : 84 - 98 dalam ejournal.an.fisip-unmul.org

Jones, O. Charles, 1984.An Introduction to the Study of Publik Police - Third Editi.California

Keban, Jeremias T, 2004 Enam Dimensi Strategi Admnistrasi Publik:Teori, Konsep dan Isu.Yogyakarta:Geva Media

Moleong, Lexy.J, 2011. Metodologi Penelitian Kualitatif. Bandung

Mariam, R.(2009)“Pengaruh Gaya Kepemimpinan dan Budaya Organisasi TerhadapKinerja Karyawan Melalui Kepuasan Kerja Karyawan Sebagai Variabel Intervening(Studi Pada Kantor Pusat PT Asuransi Jasa Indonesia (Persero)".Tesis Program Studi Magister Manajemen Pascasarjana Universitas Diponegoro, Semarang.

Rewansyah, Asnawi., 2010. Reformasi Birokrasi Dalam Rangka Good Governance". Jakarta: CV. Yusaitanas Prima

Sedarmayanti. 2009. Manajemen Sumber Daya Manusia, Reformasi Birokrasi Dan Manajemen Pegawai Negeri Sipil. Bandung : PT. Refika Aditama

Wirawan. 2009. Evaluasi Kinerja Sumber Daya Manusia : Teori, Aplikasi dan Penelitian. Jakarta : SalembaEmpat 